\title{
The International Criminal Court and the Rebels' Commitment Problem
}

Published in Civil Wars 2018 20(4): 455-476

http://doi.org/10.1080/13698249.2018.1553021

\section{Lesley-Ann Daniels*}

Institut Barcelona d'Estudis Internacionals, Barcelona, Spain,

\section{ldaniels@ibei.org}

ORCID: http://orcid.org/0000-000s-6438-8310

\begin{abstract}
$\underline{\text { Abstract }}$
There is a view that the existence of the International Criminal Court (ICC) prevents peace because rebels will not accept a peace settlement that includes accountability. This article argues that there is at least the theoretical possibility that the reverse can be true. In the presence of an international criminal authority, accountability may be unavoidable. This is true for rebels, but also for state agents, if they have also committed atrocities. Both sides may wish to avoid justice, but they have a common interest to find the minimal mutually-applicable domestic transitional justice that will deter an ICC intervention. Should the government then renege on the provisions, it risks ICC attention on its own actors, including into the future. In this way, the ICC functions as a permanent third-party guarantor of the provisions, which helps reduce the commitment problem for the rebels. This effect is conditional on certain circumstances: where both sides have committed serious atrocities, an ICC intervention is a credible threat, and both sides prefer the minimal domestic transitional justice to ICC justice. A plausibility probe case study of the adoption of justice measures in the peace agreement in Colombia finds support for the theoretical proposals.
\end{abstract}


Keywords: International Criminal Court, conflict resolution, commitment problem, peace negotiations, Colombia

The author thanks the following for comments: Miriam Bradley, Abel Escriba Folch, Mark Freeman, Scott Gates, Rafael Grasa, Enzo Nussio, Leigh A. Payne, Jack Snyder, Nils Weidmann, the editor and the reviewers. All errors of fact and judgement are my own. This work was supported by the International Catalan Institute for Peace (ICIP) through AGAUR under Grant ICIP 2011-2014. I thank the Pompeu Fabra University (UPF) for travel funds for the fieldwork. The translations are by the author. 


\section{Introduction}

In 1998, Foday Sankoh was famous for the brutal methods he authorized as rebel leader in an eight-year conflict in Sierra Leone. His followers often began their careers by murdering their own parents, and were infamous for their mutilations of civilians. Between 50,000 and 200,000 people died in the conflict (Reno 1998, Lord 2000, Gberie 2005). In 1999, Sankoh was granted a peace agreement that included a general and unconditional amnesty for the worst international crimes. ${ }^{1}$ The peace agreement included the blanket amnesty. However, the paper copy signed by the Special Representative of the United Nations Secretary General also included a handwritten note saying that his organization would not endorse the amnesty, a turning point in international justice (Freeman 2009, p. 89).

Fast forward seven years and another notoriously barbaric leader was also looking for an amnesty as part of peace negotiations. Yet Joseph Kony, rebel leader in the conflict in Northern Uganda, fell victim to changed times. By the time Kony was seeking an amnesty, he was the first person under arrest warrant from the International Criminal Court. ${ }^{2}$ Rejecting amnesties for international crimes has become the standard UN position and mediators cannot endorse such amnesties (UN Secretary-General 1999, Orentlicher 2005, van Boven 2005, UN High Commissioner for Human Rights 2009, UN Mediation Support Unit 2012). As Snyder and Vinjamuri (2003) describe it, the logic of 'consequences' has shifted to a logic of 'appropriateness'.

Civil wars are increasingly ended through peace settlements (Mason and Fett 1996, Mason et al. 1999, Toft 2010), and in recent years negotiations take place within a new framework on international criminal justice. The most explicit expression of this was the establishment of the ICC in 2002. Although there has been a long and rich debate on peace

\footnotetext{
${ }^{1}$ International crimes are crimes against humanity, war crimes and genocide.

${ }^{2}$ International Criminal Court (2005) Warrant of Arrest for Joseph Kony Issued on 8 July 2005 as amended on 27 September 2005, ICC-02/04-01/05, 27 September 2005.
} 
versus justice in normative terms, there is still remarkably little clarity on the impact of the ICC (Kritz 2009, Prorok 2017). This is important, given that the ICC is increasingly involved in conflict termination, having opened investigations in Mali, the Central African Republic and Georgia in the last few years. ${ }^{3}$ Furthermore, the court is increasingly using its propio motu powers to involve itself in conflicts where it is not invited to act, for example, in Georgia and Burundi. ${ }^{4}$ Research is also critical, given that the potential consequences are prolonged conflict and increased numbers of dead.

Much of the discussion of the ICC has been framed in terms of the peace versus justice debate, where these two concepts are presented as incompatible (Licklider 2008). ${ }^{5}$ Research has focused on how the court can act as a deterrent to entering a peace negotiation by increasing the requirement for justice. This has been developed in theoretical models and empirical research (Bass 2000, Sutter 2006, Hashimoto 2013, Krcmaric 2014, Escribà-Folch and Wright 2015, Prorok 2017). However, this article takes a different point of view and argues that once conflict parties have decided to negotiate, with the knowledge that the ICC could intervene, the ICC can have a beneficial impact. When both rebels and government forces have committed serious atrocities, they are equally susceptible to actions by the ICC. Although both sides may wish to avoid justice, they have a common interest to find the minimum mutually-applicable domestic transitional justice that will "immunize" against an ICC intervention. The threat of ICC action is present regardless of the wishes of the government, and since the ICC is a permanent court its justice requirements are binding regardless of changes in preferences of future governments. The government may wish to

\footnotetext{
${ }^{3}$ The ICC opened investigations in Mali in 2013, in the Central African Republic in 2014 and in Georgia in 2016.

${ }^{4}$ The ICC opened propio motu investigations in Georgia in 2016 and in Burundi in 2017. Other propio motu investigations include Côte d'Ivoire in 2011, and Kenya in 2010, and preliminary investigations initiated by the court are underway at the time of writing in Afghanistan, Colombia, Guinea, Iraq/UK, Nigeria, Palestine, the Philippines, Rohingya/Myanmar, Ukraine and Venezuela.

5 Though see Lutz (2006) for a more nuanced view.
} 
backslide on the domestic transitional justice, for example by reducing justice for its own actors, but such an action will attract the spotlight of the ICC and a possible intervention. Even without acting, the ICC thus behaves like a guarantor of the justice provisions of the peace agreement, both now and into the future. The knowledge that this backstop is a permanent presence enables the rebels to commit to peace, knowing that it is in the interest of future governments stick to the justice agreements and avoid atrocities. The article also examines the circumstances under which the ICC can have this effect, in order to specify how generalizable the theoretical contribution is. Firstly, both sides must have committed substantial atrocities. In the case of the state, there must be some desire to protect the actors implicated. Secondly, the ICC threat to intervene must be perceived to be credible now or in the future. Thirdly, both sides must prefer minimal domestic transitional justice to ICC justice.

Given that the Rome Statute came into force in 2002, research is still exploring the effects of the ICC through case studies that allow theory-building and the examination of scope conditions. Current examples of cases that would fit the criteria come from different parts of the world and include Nigeria, the Philippines, Ukraine and Colombia. Examples from the past would include Bangladesh, Guatemala and other Latin American countries. The article looks at the peace negotiations and implementation in Colombia as a plausibility probe of the theory. This is a rich case that includes peace negotiations before and after the ICC, and where the current peace settlement included detailed and repeated ICC involvements. The case shows support for the theoretical claims, and helps us distinguish under which circumstances an external judicial authority such as the ICC has an effect.

This article thus enriches the argument about the impact of the ICC and brings a novel new angle to the discussion. The article moves beyond the dichotomous peace versus justice debate and presents an argument that the ICC can make reaching peace easier in some 
circumstances. The article joins recent research that takes a more nuanced view on peace and justice, arguing that justice can contribute to peace (Lutz 2006, Roht-Arriaza 2006, RohtArriaza and Mariezcurrena 2006, Sriram 2010). The article also contributes by increasing the empirical rather than normative work on the impact of the ICC on peace processes (Vinjamuri and Snyder 2004, Kritz 2009).

The article's findings lead to some implications for policy. A key point arising from this research is that the ICC can have an effect as an external guarantor if the parties perceive that the ICC could act against state actors. Helping the ICC develop more "bite" could ensure more positive peace outcomes. Also, the ICC presence in the background of peace negotiations can be used to help rebels realise that justice cannot be evaded and that the ICC can be an external guarantor of justice.

\section{Literature Review}

The purpose of the ICC is to provide a court of last resort for the most atrocious crimes - war crimes, crimes against humanity and genocide. It has jurisdiction over any state that has ratified the Rome Statute (at the time of writing, 123 countries are State Parties) and over crimes committed after 1 July $2002 .^{6}$

It is still an open question on whether the impact of the ICC is positive or negative. In part, this lack of clarity arises because much of the discussion is normative (Vinjamuri and Snyder 2004). The so-called 'legalists' advocate trials and accountability and are against amnesties. Amnesties are opposed because 'wrongdoing must be punished' (Sriram 2004, p. 7), and for legal, moral, and political reasons. ${ }^{7}$ However, some scholars have argued that the

\footnotetext{
${ }^{6}$ Or the (later) date applicable to that State Party.

${ }^{7}$ The legal arguments revolve around the need to abide by domestic or international law (particularly the duty to prosecute) (Roht-Arriaza 1990, Orentlicher 1991, Scharf 1996); the moral arguments tend to focus on the obligation to victims (Chapman and van der Merwe 2008); while the political arguments consider the danger of
} 
ICC makes it harder to reach a deal. The so-called 'pragmatists' argue that trials or the threat of trials can damage a peace process because when incumbents foresee the threat of trials a settlement is less likely because it is costlier for leaders to leave power (Sutter 2006, Licklider 2008, Hashimoto 2013, Krcmaric 2014, Escribà-Folch and Wright 2015, Prorok 2017). Gissel (2015) argues that the peace negotiations in Uganda from 2006-2008 were unsuccessful because an acceptable compromise position on justice could not be reached. Prorok (2017) also finds that active involvement by the ICC can decrease conflict termination in certain circumstances. Yet, Simmons and Danner (2010) argue that the states most vulnerable to an ICC case sign up to the court in order to self-bind themselves into justice. Studies also find that the possibility of ICC action can affect perpetrators' decisions about strategy (Akhavan 2009, Grono and de Courcy Wheeler 2015, Hillebrecht 2016, Jo and Simmons 2016). Looking at conflict termination, Unger and Wierda (2009) do not establish whether international justice is systematically positive or negative on conflict outcomes, while Akhavan (2009) finds that the threat of international criminal justice did not prevent peace. In summary, the question is still open whether the ICC has a positive or negative impact on peace settlements and under what circumstances. I add to the discussion by examining the effects of the ICC within negotiations when an international criminal justice system is taken as inevitable. The ICC may be a deterrent to entering negotiations, due to the higher entry price, but have a beneficial impact once parties have entered negotiations. I propose an original argument that when both sides have an incentive to avoid the ICC spotlight it is theoretically possible for the ICC to be seen as a guarantor of a peace agreement.

a victims' retaliatory justice and the deterrent value of trials as 'the most effective insurance against future repression' (Bass 2000). 


\section{Theoretical Argument}

I start the theoretical argument with the recognition that the international criminal regime is here to stay. Whereas previously two actors were involved, now there are three. The rebels and the government can reach a settlement on justice, but any settlement is now nested within a situation where there is the possibility of an ICC action after the conclusion of the peace negotiations (Putnam 1988, Tsebelis 1990). The two parties must therefore pre-emptively take the ICC preferences into account.

When both rebels and state agents have committed serious atrocities, they are targets for ICC attention. In the past, states could hand out blanket amnesties to accommodate rebels (Melander 2009), but such amnesties are no longer internationally acceptable (Mallinder and Hadden 2013). Although both sides may wish to avoid justice, they have a common interest to find a mutually-applicable domestic solution to post-conflict transitional justice that will deter an ICC action. ${ }^{8}$ They use domestic transitional justice to "immunize" against ICC justice.

Given that the ICC could act into the future, this possibility for the ICC to intervene prevents the government, and future governments, from backsliding on the mutuallyapplicable domestic justice. The theoretical argument draws on the bargaining theories of civil war termination (Fearon 1995, 2004, 2013, Reiter 2003, Walter 2009). One of the key blockages to a compromise is the commitment problem, whereby a rebel group cannot trust the government to stick to its promises (Ginsburg 2009, Walter 2009). One well-researched solution is that third-party states or organizations act as guarantors of the peace agreement (Walter 1997, 2002, Doyle and Sambanis 2000, 2006, Fortna 2008). In part this is through institutionalizing international norms into negotiations and peace agreements. Third-party

\footnotetext{
${ }^{8}$ Under the principle of complementarity, the ICC will not act if it considers that the state is willing and able to act against perpetrators.
} 
actors can also reduce the possibility to cheat, by keeping post-conflict behaviour in the spotlight. Transferring this argument to justice, the knowledge that the ICC is in the background as a threat means justice norms are present as a reference point and as a "floor", below which justice cannot drop (Jo and Simmons 2016). It also acts as an enforcement on the government, ensuring that it remains committed to the justice provisions agreed on past actions and into the future. On the one hand, the ICC is less likely to act if the government raises justice on the rebels, though the state may be so keen to avoid any spotlight on postconflict justice due to its own misdeeds that it also avoids increasing punishment on the rebels. The logic is the same as Nalepa's "skeletons in the closet" argument, whereby the "enabling power of skeletons" in the opposition closet restrained the opposition from implementing retribution (Nalepa 2010, p. 216). On the other hand, the government will avoid reducing the requirements on its own actors. A reduction in responsibility for state actors is threatening for the rebels, as a lack of consequences for state actors could expose the rebels to atrocities when they are at their most vulnerable, in the post-conflict period. Yet such a reduction is justice is also the situation likely to provoke an ICC intervention. Thus, the knowledge that the ICC can intervene enables the rebels to trust that the government will stick to the justice provisions agreed and not renege on its promises. Should the government renege, the rebels can deploy the same boomerang techniques deployed by human rights activists to leapfrog the state and appeal directly to the ICC to intervene (Keck and Sikkink 1998). The ICC thus plays the role of the third-party guarantor of the peace agreement, ${ }^{9}$ and ceteris paribus this makes peace easier to reach.

\footnotetext{
${ }^{9}$ Note that the ICC plays this role even if it is not actively involved in the peace negotiations.
} 


\section{Conditions}

I turn now to look at the conditions that should be in place for the ICC to be credible as the guarantor of the peace agreement. The first condition is that both sides have committed atrocities that are sufficiently serious. This situation is not an unusual occurrence, with estimates that in a third of conflicts both sides have committed one-sided violence against civilians (Eck and Hultman 2007). The ICC presents the requirement of justice as a technical issue that is separate from political considerations. Therefore, justice provisions must be applied even-handedly across all actors - state or rebels. Thus, when government troops or state agents are guilty of international crimes, the justice provisions apply equally to them. Both sides therefore have an incentive to avoid an ICC intervention and so seek a peace settlement that includes the minimum domestic transitional justice to ensure that the ICC will not intervene.

The second condition is that the threat of ICC intervention must be perceived to be credible. ${ }^{10}$ The ICC has serious constraints on its time, budget and ability to carry out investigations. It also has no enforcement power. The ICC relies on the compliance of the state involved, which is difficult when the accused are state actors, especially leaders. However, for the ICC to overshadow negotiations it not necessary that it act, but rather that there is a fear it might act, not only now but also into the future. The ICC has three paths to intervention - if invited by one of the State Parties (on that state's territory), ${ }^{11}$ by propio motu (within the territory of a State Party), or if mandated by the UN Security Council, in any country. ${ }^{12}$ Studies have shown that even without enforcement power the ICC can have an

\footnotetext{
${ }^{10}$ For the purposes of this discussion I am focusing on the ICC. However, these points apply not only to the ICC as an institution, but to the international criminal regime. This can encompass the principle of universal jurisdiction, where national courts can try the gravest crimes against humanity, even if these crimes are not committed in the national territory. It can also encompass the vaguer notion of an international norm, which can empower domestic actors.

${ }^{11}$ Uganda, Democratic Republic of Congo, the Central African Republic, and Mali have referred situations to the court.

12 The UN Security Council has referred situations in Sudan (Darfur) and Libya.
} 
effect. A body of research finds that perpetrators' take international justice into account when deciding what strategy to use (Akhavan 2009, Grono and de Courcy Wheeler 2015, Hillebrecht 2016, Jo and Simmons 2016). Both Akhavan (2009) and Grono and de Courcy Wheeler (2015) examine cases where the threat of trial successfully acted as a deterrent for violence and Hillebracht (2016) finds the same with respect to Libya. Likewise, a number of member states recently threatened to withdraw from the court and we could consider these as revealing the fear that those leaders had of a possible intervention, since many were initiated by culpable leaders. ${ }^{13}$ Interestingly, most of the plans have been dropped. ${ }^{14}$

Increasingly, studies examine the conditional nature of this effect. Gilligan (2006) shows theoretically that when the risk of being deposed is high, some leaders will prefer to voluntarily surrender to the international court, while Prorok (2017) establishes this empirically. Thus, the effect can vary according to potential domestic consequences. Also, Jo and Simmons (2016) show that the deterrent effect is strongest on governments that are vulnerable to external pressure and when there are mobilized domestic and international human rights organizations. ${ }^{15}$ We see that the ICC can have a reputational effect. I consider that the ICC's soft power is an important part of its arsenal.

I argue we should also distinguish between current state leaders and former leaders, and that the court has different opportunities in such situations. In particular, action against former leaders is easier for non-responsible leaders to push through, in the same way that non-responsible leaders find it easier to end wars (Prorok 2018). Such an action can be particularly powerful as a way of symbolically turning a page of past behaviour and setting

\footnotetext{
${ }^{13}$ For example, Kenyatta in Kenya, Dutarte in the Philippines, Yahye Jammeh in Gambia. In the case of Burundi, withdrawal was initiated after the ICC in 2016 opened a preliminary investigation into crimes against humanity. Even when a country does withdraw, the ICC still has jurisdiction over the time that the country was within the Rome Statute. For example, the ICC is proceeding with a full investigation in Burundi.

${ }^{14}$ Gambia, South Africa, Kenya and Zambia have all reversed their decisions.

${ }^{15}$ Proposals to leave the court have been deeply unpopular in some countries, for example, Zambia rejected such a proposal by $91 \%$ in a popular referendum.
} 
the tone for a new way of acting. In these cases, the ICC can be a useful and powerful tool. The most resonant example in international justice (though not an ICC case) is that of Charles Taylor, who attempted to go into exile, but was arrested on the orders of the new leader. The ICC has successfully acted against former leaders in Cote d'Ivoire and Libya. ${ }^{16}$

Clearly, compliance is not possible in all situations, ${ }^{17}$ but for my argument is sufficient that the ICC is perceived as having the potential to act, now or in the future, which no leader can guarantee.

The third condition is that the minimal domestic transitional justice must be seen as preferable to ICC justice. Some have argued that actors may prefer international justice that ensures due process and accused rights, whereas domestic treatment can include torture, extrajudicial killing or the death penalty. However, this argument is applicable in cases of victor's justice. The argument here applies to negotiated settlements, where both sides have some capacity to make demands (or there would be no need for negotiation). Both sides have a common interest in finding a mutually-acceptable minimal solution. This article follows the Gilligan (2006) and Prorok (2017) point that the domestic consequences affect which option is preferable and argues that domestic transitional justice will be seen as a better option when it is less of a threat than international justice. The government may wish to backslide on the mutually-applicable domestic transitional justice, for example by reducing justice for its own actors, but such an action will attract the spotlight of the ICC and the possibility of ICC intervention. ${ }^{18}$ Thus, rebels are protected for actions against them into the future.

Some current conflicts from different parts of the world that fulfil the three conditions include Nigeria, Colombia, Ukraine and the Philippines. All are State Parties (or were so

\footnotetext{
${ }^{16}$ Gambia and South Africa both proposed leaving the court and the decision was reversed when a new leader came to power.

${ }^{17}$ Jo and Simmons (2016) argue that ICC actions have to be part of a package.

${ }^{18}$ Rebels are likely to be more reassured in democratic states where we can expect a separation of powers. For example, India, the Ukraine, Colombia, Mali, Nigeria, Senegal, Burundi, Georgia, Central African Republic, the Philippines are all democratic states that have conflicts.
} 
during the period in question) or have accepted ICC jurisdiction; all have conflicts where atrocities have been committed by both sides; and all have domestic legal systems sufficient to ensure domestic transitional justice. All are also already under the spotlight of the Office of the Prosecutor (OTP). Looking to the past, we can think of counterfactual cases such as Guatemala (now a State Party and where past leaders were tried under universal jurisdiction) and Bangladesh (now a State Party) where rebels suffered genocides and we can speculate that the rebels could have used the presence of the ICC as leverage during negotiations and reassurance in the post-conflict period. In the next section I take Colombia as a case study and trace the evolution of ICC involvement.

\section{Methodology and Case Selection}

Case study here is justified because to date we have few examples of the impact of the ICC on peace settlements. I examine Colombia as a diagnostic case that can illustrate the feasibility of the hypothesis (Gerring and Cojocaru 2016). The purpose of such a case study is to "illustrate the content of the theory and demonstrate its plausibility" (Gerring and Cojocaru, 2016, p. 405). The case study can also define the scope conditions that affect the generalizability of the hypothesis. But note, my intention is to make a theoretical argument that the ICC could work in the way proposed. My argument looks to the future potential of the ICC and in particular the advice that if the ICC had more bite it would be perceived as more credible and hence able to play this positive role.

Colombia is a case where the ICC is likely to have an impact. Colombia was an early adopter of the Rome Treaty and became a State Party in 2002. The country also has a strong record in signing up for international treaties having ratified 14 of the 18 human rights treaties. While the justice system is not the strongest in the region - in an international comparison of justice systems (World Justice Project 2017), Colombia scores at the lower 
end of both the region and its income group - it has shown that it is effective by successfully imprisoning paramilitary and rebel leaders. It has tried Revolutionary Armed Forces of Colombia (FARC, Fuerzas Armadas Revolucionarias de Colombia) leaders in absentia, with sentences up to 40 years. It has also shown that it is independent of the government, by acting against the military. Under the complementarity rule the ICC should not need to intervene if Colombia shows itself willing and able to act. Furthermore, the Colombian constitution has long condemned amnesty and the current constitution of 1991 excludes amnesty for acts of ferocity and barbarity. Thus, this is a case where we would expect the state to be receptive to ICC influence. Colombia is also a rich case because the ICC opened a preliminary examination of Colombia in 2004, which makes Colombia one of the earliest and longestrunning cases of ICC involvement.

This research uses triangulation to strengthen the interpretation of evidence. I use a range of primary sources - press releases, autobiographies and written testimonies - and secondary sources - press coverage and third-party assessments. I also draw on in-depth semi-structured interviews with 25 respondents in Bogota and Cali, Colombia; The Hague; and in Barcelona in May-June 2015 during the negotiations of the peace agreement with FARC. These interviews were carried out with representatives of the ICC; the government; governmental organizations; the army; the FARC; other ex-guerrillas and ex-paramilitary fighters; national and international non-governmental organizations (NGOs), including human rights organizations; inter-governmental organizations; and academic specialists. ${ }^{19}$

\footnotetext{
${ }^{19}$ These interviews followed the ethical code of the American Psychological Association.
} 


\section{Colombia: Case Description}

I start by giving an overview of the armed conflict and previous negotiations in Colombia. I then review recent negotiations, within the context of the ICC, and examine the evidence for the ICC alleviating the rebels' commitment problem.

Colombia has been democratic for more than 150 years. For many years, political power was controlled by the Conservative Party and the Liberal Party, who both represented the upper classes, and who eventually pacted to share rule. The current conflict started in $1964,{ }^{20}$ set up by left-wing guerrillas who reacted to the closed political system by launching an insurgency. Estimates of the death toll vary, but some sources say 220,000 people died between 1958 and 2012 (Restrepo et al. 2006, Centro Nacional de Memoria Histórica 2013) .

Throughout the conflict, efforts were made to end the violence. These efforts oscillated between the carrot and the stick (Narvaez Gomez 2009). Previous settlements did not guarantee security for the rebels. A prime example was the settlement with the FARC in 1984, which allowed FARC to establish the Patriotic Union political party (UP, Unión Patriótica). In the years following, the UP was subject to what Gomez-Suarez (2007) has described as a genocide, with estimates of those killed ranging from 3,000 to 5,000 people. During the early 1990 s, peace was made with various rebel groups. ${ }^{21}$ Amnesty, pardon and cessation of legal proceedings were included in all the peace settlements, but were accompanied by few actual political concessions. Waldman (2007) calls this the "small agenda", where rebels receive armistice and amnesty so long as they drop wider demands for economic, social and political reform (the "large agenda").

\footnotetext{
${ }^{20}$ I measure the start date according to the UCDP/PRIO ACD (Themner and Wallensteen 2012).

${ }^{21}$ M-19, the Popular Liberation Army (EPL), Quintín Lame and the Workers' Revolutionary Party (PRT) along with a breakaway section of the National Liberation Army (ELN) called the Socialist Renovation Movement (CRS)
} 


\section{The ICC in Colombia}

The Colombian government signed the Rome Statute in 1998 and ratified this document on 5 August 2002. From this time onwards, the ICC had jurisdiction over crimes against humanity and genocide. ${ }^{22}$ All sides committed atrocities that come under the jurisdiction of the ICC, including a large number of kidnappings by the guerrillas, massacres by the paramilitaries, and cases of "false positives" killings by the armed forces, where state forces killed civilians in order to claim them as terrorists (Office of The Prosecutor 2012). When the Prosecutor Luis Moreno Ocampo took office (16 June 2003), he identified Colombia, along with DRC and Uganda, as one of the situations with gravest crimes against human rights (Office of The Prosecutor 2010). However, he chose not to concentrate on Colombia at this time since national proceedings were already under way.

During this period, negotiations were going on between the government of Alvaro Uribe and the United Self-Defence Forces of Colombia (AUC, Autodefensas Unidas de Colombia), paramilitary groups that set up in many parts of Colombia to fight the guerrillas and who went on to control the drug trade and who committed many human rights abuses. The AUC is not a key example for my argument because the AUC were paramilitaries, allied to the state, ${ }^{23}$ and therefore not subject to the same commitment problem as rebels experience. However, some issues do serve to highlight my argument. The first is that the ICC was perceived as a threat and influenced the AUC decision making. Specifically, the leader, Carlos Castaño, was very conscious of the threat of ICC prosecution, which was one of the key factors in the desire to demobilize (La Semana 2005). The second is that domestic arrangements were preferable to ICC justice. Demobilization became conditional on "legislative security", under the protection of a sympathetic president (La Semana 2005). The

\footnotetext{
${ }^{22}$ Colombia made use of an option, under Article 124 of the Rome Statute, that the court would not have jurisdiction over war crimes for 7 years, so ICC jurisdiction over war crimes began on 1 November 2009. ${ }^{23}$ See the works by Carey and Mitchell, for a discussion of progrovenment militias, for example Carey \& Mitchell, 2016, 2017.
} 
third is that the ICC raised the floor of justice, as the government increasingly had to incorporate international justice norms into the legislation. Early on, Uribe attempted to introduce a law that was effectively an amnesty for international crimes, ${ }^{24}$ which did not mention the ICC or the higher authority of international law, even though this was now part of Colombian domestic law (Carrillo 2009). ${ }^{25}$ The proposed law gave rise to internal and international disgust and the OTP opened its preliminary examination into Colombia in June $2004,{ }^{26}$ 'to send a message about [the proposed] law', ${ }^{27}$ and right from the beginning, the OTP included state actors (politicians and military personnel) in the scope of potential ICC action (ICC 2009, p. 13).

The government then proposed an alternative law - the Justice and Peace Law of $2005 .{ }^{28}$ ICC impact is evident in explicit references to international norms and the inclusion of prison for most responsible leaders (Office of The Prosecutor 2012). ${ }^{29}$ Thus, we see that the possibility of an ICC intervention raised the floor for the level of justice.

\section{Negotiations with FARC}

The more relevant example for my argument is the negotiations with the rebel group FARC, which opened in September 2012, with five points for negotiation: reform of political participation, land policy, drug policy, the human rights of victims and their access to truth, and how to end the conflict.

I look first at how Colombia fulfils the three conditions. The first is that state actors were also guilty of international crimes. From the very first opening of the preliminary

\footnotetext{
24 The Law of Alternative Punishment of 2003.

${ }^{25}$ The paramilitaries were already demobilizing under Law 782 of 2002 and Decree 128 of 2003, which allowed amnesty for rank and file fighters but not for atrocious crimes.

${ }^{26}$ The first time this is made public is in 2009 in the Fifth Report of the International Criminal Court to the United Nations (ICC 2009).

${ }^{27}$ Personal communication, Camilo Sanchez, Bogota, Colombia, 3 June 2015

${ }^{28}$ Law 975 of 2005,25 July 2005 . This did not originate solely with Uribe, and in fact some parts came from the opposition (Palau van Hissenhoven 2006).

${ }^{29}$ Also, personal communication, member of Transitional Justice Fund, Bogota, Colombia, 22 May 2015
} 
examination in Colombia in 2004, the OTP has included in the examination government actors and supporters alongside the rebels. Throughout the OTP interventions, there have been numerous references to the "false positives" killings.

The second condition is that the ICC threat be perceived to be credible. As we saw, the AUC took the threat of an ICC intervention seriously. Even ex-president Pastrana had already privately expressed his fears about being the focus of an ICC prosecution (Bloomfield 2007). Furthermore, Colombia has a well-established legal tradition, is conscious of its international reputation, and has a strong Constitutional Court that would likely rule that the government had to abide by any instructions. The OTP has already stated that she is considering moving from preliminary investigation to investigation, and would order the accused to attend trial in The Hague (Alsema 2018). Colombia's international reputation would be severely compromised if it refused to collaborate.

The third condition is that the actors must prefer minimal domestic transitional justice to ICC justice, so that ICC justice is the bigger threat. The level of transitional justice imposed on the AUC did not trigger an ICC intervention. As we shall see, the FARC ended up seeking legislative security and the level of justice proposed seemed to be sufficient to deter an ICC intervention. Recent ICC comments focus most on the moves to reduce justice on the government side.

The example of the FARC highlights my argument in a number of ways. Firstly, the FARC came to accept the ICC presence. The ICC is only a facilitator to a peace deal once the parties accept that the ICC is able to intervene. The FARC negotiators went into the talks from a highly isolated group that had been carrying out jungle-based insurgency for almost 50 years. At the early stage of negotiations, the FARC rejected the whole idea of transitional justice, with its emphasis on individual criminal accountability, saying it was 'an invention of 
the United States'. ${ }^{30}$ The shift for the FARC negotiators to realizing that the ICC was an unchangeable part of the structure within which the negotiations had to happen took years. Yet by the end of the process President Santos set up a six-person committee (three for the government and three for the FARC) primarily composed of lawyers, who positioned their negotiating space within the range of what would be acceptable to international justice.

Observers credit this committee with being crucial to finding a settlement. ${ }^{31}$ The FARC strategy shifted from one of opposition to justice to a controlled use of domestic justice in order to avoid international justice. ${ }^{32}$ "They recognize the importance of "judicial security", i.e. that the legal situation is well tied up and that they will not be chased in the future'. ${ }^{33}$

We also see that the presence of the ICC raises justice. Throughout the negotiations the ICC increased its involvement in Colombia, with visits and round-table discussions to discuss the requirements for international justice. At various points in the negotiations the government proposed acts that violated the Rome Statute, such as the Legislative Act 01 of 2012, known as the Framework for Peace Law. ${ }^{34}$ This law was generous on accountability, stating that only the most responsible for only the most heinous crimes should be targeted for criminal proceedings (i.e. crimes that ought to be tried under international law might not be prosecuted if those committing them were not the most responsible). Also, cases could be prioritized (i.e. some cases that break international law may be relinquished). These points in particular are important to state actors. Furthermore, sentences could be suspended, i.e. postponed and possibly dropped. The OTP repeatedly responded that proceedings should "focus on or include persons bearing the greatest responsibility" (Office of The Prosecutor

\footnotetext{
${ }^{30}$ Personal communication, Camilo Sanchez, Bogota, Colombia, 3 June 2015

${ }^{31}$ Personal communication, ex-FARC commander, Barcelona, Spain, 21 December 2015

${ }^{32}$ A possible metric for ICC impact is the speed of reaching a peace accord. However, given the starting point for FARC in the Colombian negotiations, I consider their shift in the rhetoric around justice to be a more appropriate indicator. I choose rather to focus on the content of the agreements and the way the actors talk about them.

${ }^{33}$ Personal communication, academic, Bogota, Colombia, 9 June 2015

${ }^{34}$ ICTJ, Legislative Act 01 of 2012, https://www.ictj.org/colombia-timeline/index_eng.html, accessed 28 July 2017. This law was passed by the government on 27 December 2012.
} 
2012, p. 16) ${ }^{35}$ and to push for increased justice (Stewart 2015). Following this criticism,

Santos set up the six-person committee on justice mentioned above. This committee drafted the Special Jurisdiction for Peace (JEP, Jurisdicción Especial para la Paz), which was included in the Agreement on Victims of the Conflict announced on 15 December 2015. ${ }^{36}$ Perpetrators who confessed to atrocities ${ }^{37}$ would be allocated a restorative and reparative sanction of up to eight years with perpetrators exempt from jail. Those who do not volunteer a confession lose the benefits of the special jurisdiction, and punishments include an effective deprivation of liberty, for between 15 and 20 years.

\section{Post-agreement Developments}

The peace deal was put to a popular referendum on 2 October 2016, with the aim of achieving popular buy-in for the terms of the peace. Throughout negotiations, the right-wing, led by ex-president Uribe, was opposed to the perceived generous judicial treatment for guerrillas and they campaigned hard against the deal. The peace agreement failed to get approval in the referendum, by a narrow margin and on a low turnout, even though the areas that had suffered the worst atrocities voted in highest proportions for the agreement (Marcos 2016). On 14 November 2016, the parties published the new peace deal, revised in consultation with the right-wing opposition, and incorporating stricter provisions on restrictions of liberty. ${ }^{38}$ However, this new peace deal retained a previous exemption from

\footnotetext{
${ }^{35}$ The text also refers to Article 17 of the Rome Statute, which defines when the court would intervene if it considers that a State is unwilling to prosecute, where unwillingness is judged by not prosecuting perpetrators, using criminal judgements nationally to shield the person from more serious crimes, or by other indicators such as delay, non-independence or non-impartiality.

${ }^{36}$ Acuerdo sobre la Víctimas del Conflicto [Agreement on Victims of the Conflict], 15/12/2015, available at http://equipopazgobierno.presidencia.gov.co/acuerdos/Documents/acuerdo-punto-victimas.pdf, last accessed 20/2/2018

${ }^{37}$ Defined in Article 40 as crimes against humanity, genocide, serious war crimes, hostage taking or another severe deprivation of physical liberty, torture, extrajudicial executions, forced disappearance, violent sexual intercourse and other kinds of sexual violence, child abduction, forced displacement, as well as the recruitment of minors.

${ }^{38}$ Acuerdo Final para la Terminación del Conflicto y la Construcción de una Paz Estable y Duradera [Final Agreement for the Termination of the Conflict and the Construction of a Stable and Lasting Peace], 24/11/2016,
} 
command responsibility that provided some leeway around international law. ${ }^{39}$ This

exemption is important to the military and state actors because they cannot dismiss the "false positive" killings as the actions of some over-zealous bad apples in the security forces, but rather responsibility is traced back to the commanding officers. ${ }^{40}$ As the law progressed through the legislative stages, command responsibility was increasingly watered down for the state actors, often with pressure from the military (Isacson and Sanchez-Garzoli 2017). Likewise, the requirements for civilians to appear was reduced, making their appearance voluntary and making it harder for the Special Jurisdiction for Peace to gather sufficient evidence. Compulsory attendance had been seen as a big sticking point for the business community, who feared being forced to face the court. The OTP again intervened at various times to instruct the legislators on command responsibility and the appearance of noncombatants before the courts (Bensouda 2017, El Colombiano 2017, La Semana 2017). Following these proceedings, the ex-leader of FARC and political candidate, Rodrigo Londoño (Timochenko) took the unprecedented step of appealing to the ICC to enforce strictly the justice provisions in the peace agreement (Londoño 2017). The FARC have lived with the memory of their murdered colleagues who previously tried to turn to politics through the Patriotic Union. For them, a reduction in responsibility for state actors is directly a threat to their lives and security in the post-conflict period. They look to the ICC to guarantee the provisions, which shows support for the argument proposed here.

\footnotetext{
available at http://www.altocomisionadoparalapaz.gov.co/procesos-yconversaciones/Documentos\%20compartidos/24-11-2016NuevoAcuerdoFinal.pdf, last accessed 20/2/2018

${ }^{39}$ This legal doctrine is codified in Article 28 of the Rome Statute and states that even if leaders themselves did not act, they are responsible for actions carried out by their subordinates if they knew or, owing to the circumstances at the time, should have known that subordinates had committed or would commit atrocities. ${ }^{40}$ An ex-colonel of the army stated "There was torture. There were "false positives", but these were a few (2030) individuals who went beyond the limits. They should answer for their crimes." (personal communication, Bogota, Colombia, 1 June 2015) However, the Centre for Historical Memory stated "The army claim crimes were committed by a few rotten apples, but institutions like the Centre for Historical Memory find thousands of crimes. This is rotten apples or institutional policy?" (personal communication, Gonzalo Sanchez, 25 May 2015 , Bogota, Colombia)
} 
In 2018, presidential elections took place and the right-wing candidate ran on opposition to the peace agreements and a pledge to increase prison for the FARC. Yet at the time of writing, the pro-Uribe president, Ivan Duque, has dropped the intention to unilaterally increase the level of justice on the rebels, even though this was an explicit election promise (El Espectador 2018). Duque does not feel able to unilaterally increase justice against the rebels, even though he still refers to three other proposed changes. ${ }^{41}$ On the other hand, the government's attempts to reduce justice for state actors is meeting increasing resistance from the Prosecutor. The Prosecutor visited Colombia in September 2017 and again in March 2018, emphasizing that her office had evidence against the military and now specifying 23 generals and 6 colonels, and stating her intention to open formal criminal investigations, which would allow the OTP to call for the military commanders to be transferred to the Hague to stand trial (Alsema 2018). These comments are a strong escalation in the Prosecutor's rhetoric.

Thus, we can see that after the signing of the peace agreement, the government attempted to soften provisions on justice for state agents and civilian and third-party state supporters. It is striking that the FARC aligned themselves with the OTP to protest at the dilution of the justice provisions. For the FARC, a reduction in state responsibility is a direct threat to their security into the future. The FARC see the OTP as the guarantor of the justice provisions and of their commitment problem. When the government has attempted to soften provisions on justice for state agents and civilian and third-party state supporters, the OTP has escalated her rhetoric and stated more explicitly her intention to act. The new government also seems to have dropped its plan to impose harsher justice on the rebels. The government cannot act without taking into account the framework of the ICC and the level of domestic

\footnotetext{
${ }^{41}$ Preventing the guaranteed political posts to FARC, including drug dealing as a political crime, and forced eradication of the coca production.
} 
transitional justice that was agreed with the FARC and is supported by the ICC. Far from being just a theoretical possibility, we see that the ICC is acting as external guarantor in Colombia.

\section{Conclusion}

The ICC has been an influence on international justice since 1998. States that have ratified the Rome Statute pass their judicial sovereignty to the ICC, while even non-State Parties are affected since the ICC can take jurisdiction under a UN Security Council mandate.

Negotiations between the government and the rebels are now nested inside a possible compromise with the ICC.

This article puts forward an original argument that the ICC could have a positive outcome on peace negotiations. Firstly, during peace negotiations, conflict parties anticipate the possibility of an intervention by the ICC and so private deals are no longer possible. The presence of the ICC raises the floor of justice as both sides search for the level of transitional justice that will "immunize" against an ICC intervention. Beyond the peace negotiations, as a permanent presence, the ICC acts like an external guarantor who can alleviate the rebels' commitment problem. After the rebels surrender and decommission, they lose their leverage to ensure that the state sticks to its promises. The presence of an external party that has authority over justice can relieve the rebels' commitment problem against future betrayal by the state, particularly the reduction of responsibility for state actors that could expose rebels to potential atrocities. This is important, because the rebels are most vulnerable in the postconflict period.

Clearly, the ICC will be effective only under certain conditions and this article specifies what those would need to be - in situations where state actors have also committed serious international crimes, when an ICC intervention is credible either now or in the future, 
and when pacted domestic transitional justice is preferred to ICC justice. Current cases that could meet these criteria include Nigeria, the Philippines, Ukraine and Colombia, while counterfactual cases from the past include Bangladesh, Guatemala and other Latin American countries. A case study of Colombia, a particularly long and well-documented case, shows that these conditions can be met. The case furthermore shows that the rebels moved from rejecting international justice at the beginning of negotiations to calling for the support of the ICC during the post-agreement implementation. While this is not proof that the rebels considered the ICC as a guarantor, it does support the theoretical argument that such as role is possible.

Third parties can be unreliable guarantors for rebels. A change of government or regime can bring a change of support. By contrast, the ICC is now part of the international justice landscape. It has been set up as a permanent court. Furthermore, the ICC does not need to act to have an effect. It is sufficient that it is there as a presence, "a hidden negotiator". ${ }^{42}$

The article therefore puts forward an original argument that is shown to be feasible in a recent case. The argument has implications for policy. Firstly, helping the ICC develop more "bite" could ensure more positive peace outcomes, since a possible intervention should be perceived as credible. Secondly, peace negotiators should persuade rebels that international justice is inevitable and that their best option is to work within the justice system.

42 Personal communication, Gonzalez Sanchez, 25 May 2015, Bogota, Colombia 


\section{References}

Akhavan, P., 2009. Are International Criminal Tribunals a Disincentive to Peace:

Reconciling Judicial Romanticism with Political Realism. Human Rights Quarterly, 31 (3), 624-654.

Alsema, A., 2018. ICC intends to file criminal charges against Colombia military chiefs [online]. Colombia Reports. Available from: https://colombiareports.com/icc-intends-tofile-criminal-charges-against-colombia-military-chiefs/ [Accessed 27 Sep 2018].

Bass, G.J., 2000. Stay the Hand of Vengeance. Princeton, NJ: Princeton University Press.

Bensouda, F., 2017. El acuerdo de paz de Colombia demanda respeto, pero también responsibilidad [Colombia's peace agreement demands respect, but also responsibility] [online]. La Semana. Available from: http://www.semana.com/nacion/articulo/deseocorte-penal-internacional-justicia-transicional-en-colombia/512820 [Accessed 9 Jul 2015].

Bloomfield, W., 2007. Ambassador's November 1 Meeting with Former President Andres Pastrana [online]. Wikileaks. Available from: https://wikileaks.org/plusd/cables/07BOGOTA8045_a.html [Accessed 25 Oct 2018]. van Boven, T., 2005. Basic Principles and Guidelines on the Right to a Remedy and Reparation for Victims of Gross Violations of International Human Rights Law and Serious Violations of International Humanitarian Law. New York: United Nations. Carrillo, A.J., 2009. Truth, Justice and Reparations in Colombia. In: V.M. Bouvier, ed. Colombia: Building Peace in a Time of War. Washington, DC: US Institute of Peace Press, 133-156.

Centro Nacional de Memoria Histórica, 2013. Basta Ya! [Enough!]. Bogota: Imprenta Nacional.

Chapman, A.R. and van der Merwe, H., 2008. Truth and Reconciliation in South Africa: Did 
the TRC deliver? Philadelphia, PA: University of Pennsylvania Press.

El Colombiano, 2017. Corte Constitucional avala Justicia Especial para la Paz [The

Constitutional Court endorses Special Justice for Peace] [online]. El Colombiano.

Available from: http://www.elcolombiano.com/colombia/acuerdos-de-gobierno-y-

farc/corte-constitucional-avala-justicia-especial-para-la-paz-NF7689681 [Accessed 27

Sep 2018].

Doyle, M.W. and Sambanis, N., 2000. International Peacebuilding: A Theoretical and

Quantitative Analysis. American Political Science Review, 94 (4), 779-801.

Doyle, M.W. and Sambanis, N., 2006. Making War and Building Peace: United Nations

Peace Operations. Princeton, NJ: Princeton University Press.

Eck, K. and Hultman, L., 2007. One-Sided Violence Against Civilians in War. Journal of Peace Research, 44 (2), 233-246.

Escribà-Folch, A. and Wright, J., 2015. Human rights prosecutions and autocratic survival. International Organization, 69 (2), 343-373.

El Espectador, 2018. El futuro de los acuerdos de paz según los candidatos presidenciales [The future of the peace accords according to the presidential candidates] [online]. El Espectador. Available from: https://colombia2020.elespectador.com/politica/el-futurode-los-acuerdos-de-paz-segun-los-candidatos-presidenciales [Accessed 21 Oct 2018].

Fearon, J.D., 1995. Rationalist explanations for war. International Organization, 49 (3), 379414.

Fearon, J.D., 2004. Why do some civil wars last so much longer than others? Journal of Peace Research, 41 (3), 275-301.

Fearon, J.D., 2013. Fighting rather than bargaining. Stanford University.

Fortna, V.P., 2008. Does Peacekeeping Work? Shaping Belligerents' Choices after Civil War. Princeton, NJ: Princeton University Press. 
Freeman, M., 2009. Necessary Evils: Amnesties and the Search for Justice. Cambridge: Cambridge University Press.

Gberie, L., 2005. A Dirty War in West Africa: The RUF and the Destruction of Sierra Leone. Bloomington, IN: Indiana University Press.

Gerring, J. and Cojocaru, L., 2016. Selecting Cases for Intensive Analysis. Sociological Methods \& Research, 45 (3), 392-423.

Gilligan, M.J., 2006. Is enforcement necessary for effectiveness? A model of the international criminal regime. International Organization, 60 (4), 935-967.

Ginsburg, T., 2009. The Clash of Commitments at the International Criminal Court. Chicago Journal of International Law, (9), 499-514.

Gissel, L.E., 2015. Justice Tides: How and When Levels of ICC Involvement Affect Peace Processes. International Journal of Transitional Justice, 9, 428-448.

Gomez-Suarez, A., 2007. Perpetrator blocs, genocidal mentalities and geographies: The destruction of the Union Patriotica in Colombia and its lessons for genocide studies. Journal of Genocide Research, 9 (4), 637-660.

Grono, N. and de Courcy Wheeler, A., 2015. The Detterent Effect of the ICC on the Commission of International Crimes by Government Leaders. In: C. Stahn, ed. The Law and Practice of the International Criminal Court. Oxford: Oxford University Press, $1225-1244$.

Hashimoto, B.M., 2013. Why Do Leaders Accept the International Criminal Court's Jurisdiction? Theory and Evidence. Shanghai.

Hillebrecht, C., 2016. The deterrent effects of the International Criminal Court: Evidence from Libya. International Interactions, 42 (4), 616-643.

ICC, 2009. Fifth Report of the International Criminal Court to the United Nations for 2008/2009, A/63/356 [online]. 17 September 2009. Available from: http://www.icc- 
cpi.int/NR/rdonlyres/1BC01710-9C42-44AC-8B18-

85EE2A8876EB/281210/A_64_356_ENG2.pdf [Accessed 9 Jul 2015].

Isacson, A. and Sanchez-Garzoli, G., 2017. Colombia’s New Transitional Justice Law Violates the Spirit of the Peace Accords [online]. Washington Office for Latin America. Available from: https://www.wola.org/analysis/colombias-new-transitional-justice-lawviolates-spirit-peace-accords/ [Accessed 20 Feb 2018].

Jo, H. and Simmons, B.A., 2016. Can the International Criminal Court Deter Atrocity? International Organization, 70 (3), 443-475.

Keck, M.E. and Sikkink, K., 1998. Activists beyond Borders: Advocacy Networks in International Politics. Ithaca, NY: Cornell University Press.

Krcmaric, D., 2014. The Price of Justice: International Criminal Accountability and Civil Conflict. Durham, NC: Duke University.

Kritz, N.J., 2009. Policy Implications of Empirical Research on Transitional Justice. In: H. van der Merwe, V. Baxter, and A.R. Chapman, eds. Assessing the Impact of Transitional Justice: Challenges for Empirical Research. Washington DC: United States Institute of Peace Press.

Licklider, R., 2008. Ethical advice: Conflict management vs. human rights in ending civil wars. Journal of Human Rights, 7 (4), 376-387.

Londoño, R., 2017. Carta de Rodrigo Londoño Timo a la señora Fiscal de la Corte Penal Internacional [Letter from Rodrigo Londoño Timo to the Prosecutor of the ICC] [online]. FARC-EP. Available from: https://www.farc-ep.co/comunicado/http-wwwfarc-ep-co-comunicado-carta-de-rodrigo-londono-timo-a-la-senora-fiscal-de-la-cortepenal-internacional-html.html [Accessed 20 Feb 2018].

Lord, D., 2000. The struggle for power and peace in Sierra Leone. In: D. Lord, ed. Accord: Sierra Leone. London: Conciliation Resources. 
Lutz, E., 2006. Transitional justice: Lessons learned and the road ahead. In: N. Roht-Arriaza and J. Mariezcurrena, eds. Transitional Justice in the Twenty-First Century: Beyond Truth versus Justice. Cambridge: Cambridge University Press.

Mallinder, L. and Hadden, T., 2013. The Belfast Guidelines on Amnesty and Accountability. Belfast: Transitional Justice Institute.

Marcos, A., 2016. Las zonas urbanas y la élite agraria de Colombia impulsaron el triunfo del "no" [Urban areas and the rural elite of Colombia drive the success of the "no" vote] [online]. El Pais. Available from:

https://elpais.com/internacional/2016/10/03/colombia/1475511558_836662.html [Accessed 15 Jul 2017].

Mason, T.D. and Fett, P.J., 1996. How civil wars end: A rational choice approach. Journal of Conflict Resolution, 40 (4), 546-568.

Mason, T.D., Weingarten Jnr, J.P., and Fett, P.J., 1999. Win, Lose or Draw: Predicting the Outcome of Civil Wars. Political Research Quarterly, 52 (2), 239-268.

Melander, E., 2009. Justice or peace? A statistical study of the relationship between amnesties and durable peace. Lund: Lund University.

Nalepa, M., 2010. Skeletons in the Closet: Transitional Justice in Post-Communist Europe. Cambridge: Cambridge University Press.

Narvaez Gomez, L., 2009. Twenty years of negotiating peace: A recipe of sticks and carrots. In: E.F. Babbitt and E. Lutz, eds. Human Rights \& Conflict Resolution in Context: Colombia, Sierra Leone and Northern Ireland. Syracuse, NY: Syracuse University Press, 46-69.

Office of The Prosecutor, 2010. Draft Policy Paper on Preliminary Examinations [online]. Available from: http://www.icc-cpi.int/NR/rdonlyres/E278F5A2-A4F9-43D7-83D26A2C9CF5D7D7/282515/OTP_Draftpolicypaperonpreliminaryexaminations04101.pdf 
[Accessed 25 Jul 2017].

Office of The Prosecutor, 2012. Situation in Colombia: Interim Report [online]. Available from: https://www.icc-cpi.int//Pages/item.aspx?name=Situation-in-Colombia-InterimReport [Accessed 5 Nov 2018].

Orentlicher, D.F., 1991. Settling accounts: The duty to prosecute human rights violations of a prior regime. Yale Law Journal, 100 (8), 2537-2615.

Orentlicher, D.F., 2005. Updated Set of Principles for the Protection and Promotion of Human Rights through Action to Combat Impunity. New York: United Nations Commission on Human Rights.

Palau van Hissenhoven, N., 2006. Tramite de la Ley de Justicia y Paz [The Enactment of the Justice and Peace Law]. Bogota: Fundación Social.

Prorok, A.K., 2017. The (In)compatibility of Peace and Justice? The International Criminal Court and Civil Conflict Termination. International Organization, 71 (2), 213-243.

Prorok, A.K., 2018. Led Astray: Leaders and the Duration of Civil War. Journal of Conflict Resolution, 62 (6), 1179-1204.

Putnam, R.D., 1988. Diplomacy and domestic politics: The logic of two-level games. International Organization, 42 (3), 427-460.

Reiter, D., 2003. Exploring the Bargaining Model of War. Perspectives on Politics, 1 (1), $27-$ 43.

Reno, W., 1998. Warlord Politics and African States. Boulder, CO: Lynne Rienner Publishers.

Restrepo, J.A., Spagat, M., and Vargas, J.F., 2006. The Severity of the Colombian Conflict: Cross-Country Datasets Versus New Micro-Data. Journal of Peace Research, 43 (1), 99-115.

Roht-Arriaza, N., 1990. State responsibility to investigate and prosecute grave human rights 
violations in international law. California Law Review, 78 (2), 449-514.

Roht-Arriaza, N., 2006. The new landscape of transitional justice. In: N. Roht-Arriaza and J. Mariezcurrena, eds. Transitional Justice in the Twenty-First Century: Beyond Truth versus Justice. New York: Cambridge University Press, 1-16.

Roht-Arriaza, N. and Mariezcurrena, J., 2006. Transitional Justice in the Twenty-First Century: Beyond Truth versus Justice. New York: Cambridge University Press.

Scharf, M.P., 1996. Swapping amnesty for peace: Was there a duty to prosecute international crimes in Haiti. Texas International Law Journal, 31 (1), 1-41.

La Semana, 2005. Vicente Castaño Habla [Vicente Castaño Talks] [online]. La Semana. Available from: https://www.semana.com/portada/articulo/habla-vicente-castano/729643 [Accessed 25 Oct 2018].

La Semana, 2017. Las cuatro críticas de la fiscal de la CPI a la Justicia Especial para la Paz [The four criticisms from the Prosecutor of the ICC to the Special Jurisdiction for Peace] [online]. La Semana. Available from: http://www.semana.com/nacion/articulo/losreparos-de-la-fiscal-de-la-cpi-a-la-justicia-especial-de-paz/544474 [Accessed 21 Nov 2017].

Simmons, B.A. and Danner, A., 2010. Credible commitments and the international criminal court. International Organization, 64 (2), 225-256.

Snyder, J. and Vinjamuri, L., 2003. Trials and errors: Principles and pragmatism in strategies of international justice. International Security, 28 (3), 5-44.

Sriram, C.L., 2004. Confronting past human rights violations: justice vs. peace in times of transition. New York: Frank Cass.

Sriram, C.L., 2010. Resolving Conflicts and Pursuing Accountability: Beyond "Justice Versus Peace.” In: O. Richmond, ed. Critical Advances in Peacebuilding. London: Palgrave Macmillan. 
Stewart, J., 2015. Transitional Justice in Colombia and the Role of the International Criminal Court [online]. Available from: http://www.icc-cpi.int/iccdocs/otp/otp-stat-13-05-2015ENG.pdf [accessed 22 July 2015] [Accessed 28 Jul 2017].

Sutter, D., 2006. The Deterrent Effects of the International Criminal Court. Conferences of the New Political Economy, 23 (1), 9-24.

Themner, L. and Wallensteen, P., 2012. Armed conflicts, 1946-2011. Journal of Peace Research, 49 (4), 565-575.

Toft, M.D., 2010. Securing the peace: the durable settlement of civil wars. Princeton, NJ: Princeton University Press.

Tsebelis, G., 1990. Nested Games: Rational Choice in Comparative Politics. Berkeley, CA: University of California Press.

UN High Commissioner for Human Rights, 2009. Rule of Law Tools for Post-Conflict States: Amnesties. New York: United Nations.

UN Mediation Support Unit, 2012. Guidance for Effective Mediation. New York: United Nations.

UN Secretary-General, 1999. Seventh Report of the Secretary-General on the United Nations Observer Mission in Sierra Leone. New York: United Nations.

Unger, T. and Wierda, M., 2009. Pursuing Justice in Ongoing Conflict. A Discussion of Current Practice. In: K. Ambos, J. Large, and M. Wierda, eds. Building a Future on Peace and Justice. Berlin: Springer, 263-302.

Vinjamuri, L. and Snyder, J., 2004. Advocacy and scholarship in the study of international war crimes tribunals and transitional justice. Annual Review of Political Science, 7, 345362.

Waldman, P., 2007. Colombia and the FARC: Failed attempts to stop violence and terrorism in a weak state. In: R.J. Art and L. Richardson, eds. Democracy and counterterrorism: 
Lessons from the past. Washington, DC: United States Institute of Peace Press.

Walter, B.F., 1997. The critical barrier to civil war settlement. International Organization, 51 (3), 335-364.

Walter, B.F., 2002. Committing to peace: The successful settlement of civil wars. Princeton, NJ: Princeton University Press.

Walter, B.F., 2009. Bargaining Failures and Civil War. Annual Review of Political Science, $12(1), 243-261$.

World Justice Project, 2017. Rule of Law Index 2016 [online]. Available from: http://data.worldjusticeproject.org/ [accessed 28 July 2017]. 